\title{
Zooplankton trophic dynamics drive carbon export efficiency
}

\author{
Camila Serra-Pompei ${ }^{1 *}$, Ben A. Ward ${ }^{2}$, Jérôme Pinti ${ }^{1}$, André W. Visser ${ }^{1}$, \\ Thomas Kiørboe $^{1}$, Ken H. Andersen ${ }^{1}$ \\ ${ }^{1}$ Centre for Ocean Life, Technical University of Denmark, DTU Aqua, Kemitorvet B201, Kongens Lyngby \\ 2800, Denmark \\ ${ }^{2}$ Ocean and Earth Science, University of Southampton, Southampton, UK.
}

\section{Key Points:}

- We used a 3D size-spectrum model of the planktonic community to understand the drivers of particulate carbon export efficiency

- We find that high temperature decreases growth efficiency, trophic transfer efficiency and associated carbon export efficiency.

- Systems that are top-down controlled by zooplankton can have high export efficiencies depending on the size of the dominant zooplankton.

\footnotetext{
*Current address, Department of Earth, Atmospheric and Planetary Sciences, Massachusetts Institute of Technology, Cambridge, MA 02139, USA

Corresponding author: Camila Serra-Pompei, camsp@mit.edu
} 


\begin{abstract}
The flux of detrital particles produced by plankton is an important component of the biological carbon pump. We investigate how food web structure and organisms' size regulate particulate carbon export efficiency (the fraction of primary production that is exported via detrital particles at a given depth). We use the Nutrient-Unicellular-Multicellular (NUM) mechanistic size-spectrum model of the planktonic community (unicellular protists and copepods), embedded within a 3D model representation of the global ocean circulation. The ecosystem model generates emergent food webs and size distributions of all organisms and detrital particles. Model outputs are compared to field data. We find that strong predation by copepods increases export efficiency, while protist predation reduces it. We find no clear relation between primary production and export efficiency. Temperature indirectly drives carbon export efficiency by affecting the biomass of copepods. High temperatures, combined with nutrient limitation, result in low growth efficiency, smaller trophic transfer to higher trophic levels, and decreased carbon export efficiency. Even though copepods consume a large fraction of the detritus produced, they do not markedly attenuate the particle flux. Our simulations illustrate the complex relation between the planktonic food web and export efficiency, and highlights the central role of zooplankton and their size structure.
\end{abstract}

\title{
Plain Language Summary
}

Plankton are small organisms that live in the ocean. Plankton remove CO2 from the atmosphere by doing photosynthesis and sinking to the deep ocean, where the $\mathrm{CO} 2$ is sequestered. Photosynthesis can be measured by satellites, and therefore, knowing the fraction of photosynthesis that sinks to the deep ocean could allow making more accurate predictions of the concentration of $\mathrm{CO} 2$ in the atmosphere. This fraction of photosynthesis that is exported is termed "carbon export efficiency". However, the drivers that define this carbon export efficiency are not well understood. To explore these drivers, we used computer simulations that include many planktonic organisms in a $3 \mathrm{D}$ model of the oceans. The model generates a detailed representation of the body sizes of plankton and of particle sizes, which is one of the main features defining sinking rates of particles in nature. We find that export efficiency is high when large zooplankton consume large amounts of prey. Temperature decreases export efficiency by reducing how efficient large plankton grow. Finally, we do not find a clear relation between photosynthesis and export efficiency, which has been much discussed in the literature. This provides mechanistic explanations to previous field observations and generates new hypotheses to be tested.

\section{Introduction}

Plankton remove atmospheric $\mathrm{CO}_{2}$ through photosynthesis and the export of organic carbon to the deep ocean (Longhurst \& Harrison, 1989; Ducklow et al., 2001). This process is termed the biological carbon pump. Global estimates of carbon export below the euphotic zone range from $\approx 3$ to $12 \mathrm{PgC}_{\text {year }}{ }^{-1}$ (Dunne et al., 2005; Henson et al., 2011; DeVries \& Weber, 2017). The large uncertainty in these estimates underscores our incomplete understanding of the biological carbon pump, preventing accurate predictions of the carbon cycle and its response to anthropogenic emissions.

A key parameter is carbon export efficiency, i.e., the fraction of net primary production (NPP) that is exported below a given depth. Export efficiency can be used, for example, to estimate total carbon export from satellite-derived NPP products (Carr et al., 2006). The most common algorithms use temperature and primary production to estimate carbon export efficiency (Laws et al., 2011; Dunne et al., 2005), generally inversely related to temperature and positively related to net primary production and large planktonic organisms (Laws et al., 2000). However, these relationships have recently been 
challenged, where an inverse relation with NPP or with biomass of large zooplankton has been found (Maiti et al., 2013; Cavan et al., 2017; Henson et al., 2019).

Community composition and interactions between organisms, such as competition and predation, are known to affect carbon export (Parsons, 1988; Aksnes \& Wassmann, 1993; Steinberg \& Landry, 2017). In terms of community composition, organisms' morphological traits influence the sinking rate of associated detrital particles. Size is an important driver of particulate sinking rates (Small et al., 1979; Bach et al., 2019). Further, multicellular zooplankton contribute to the particle flux by producing fast-sinking fecal pellets, that increase in size and sinking speed with the size of the zooplankter that produces them (Small et al., 1979; Stamieszkin et al., 2015). Thus, knowing the size-distribution of the community is a good starting point to determine sinking rates of particles and carbon export.

Predator-prey interactions may also influence carbon export and its efficiency. Zooplankton consuming primary producers at the surface may decrease carbon export efficiency due to trophic transfer losses and energy retention in the surface ocean, in particular if top-down control on primary producers is strong (Parsons, 1988). Zooplankton can also attenuate the carbon flux by consuming or fragmenting detrital particles (Wexels Riser et al., 2007, 2010; Cavan et al., 2017). Thus, whether large zooplankton increase carbon export efficiency by producing fast-sinking particles or decrease carbon export efficiency through consumption and top-down control depends on the relative contribution of the component processes. All these processes are interrelated, and which processes dominate under which conditions is still unclear.

Here we explore the drivers of plankton food web structure and associated carbon export efficiency. We use the Nutrient-Unicellular-Multicellular (NUM) size-spectrum model of the planktonic community (Serra-Pompei et al., 2020), coupled to a 3D representation of the global ocean circulation (Khatiwala et al., 2005; Khatiwala, 2007). Food web structure emerges from the model, and the model yields size spectra of plankton and detrital particles. In the model, the community is divided into unicellular and multicellular compartments that are organised along a common size axis. The unicellular compartment simulates protists and includes all trophic strategies (autotrophy, mixotrophy, heterotrophy). The multicellular compartment is parameterized to simulate copepod populations of different adult sizes and feeding modes (active vs. passive feeders), where their growth in body-size over their life is explicitly modeled. The framework encompasses the main physiological processes and predator-prey interactions. In particular, it resolves the multicellular component that is often omitted or weakly represented.

\section{Methods}

The NUM framework (nutrients-unicellular-multicellular) is a mechanistic size- and trait-based model of the planktonic community (Serra-Pompei et al., 2020). The original model resolves the size distribution of protists (autotrophic, mixotrophic, heterotrophic), the copepod community, copepod fecal pellets, and one pool of nitrogen. Here, the model has been extended to account for the size-distribution of dead cells and dead copepods, referred to as carcasses. Finally, the ecological model is embedded in a 3D transport matrix that represents the ocean physical environment, including advection and diffusion (Khatiwala, 2007). All the pools of the model are illustrated in figure 1.

Size is the main trait describing organisms. All physiological rates and predatorprey interactions are size-dependent, allowing the emergence of distinct trophic strategies across the protist size spectrum (Chakraborty et al., 2017). The copepod population model represents the life-cycle of copepods by linking individual life-history processes to population dynamics. Each population is represented by the adult size and the feeding mode (active feeders vs. passive 'sit-and-wait' ambush feeders). The food web con- 
bioRxiv preprint doi: https://doi.org/10.1101/2021.03.08.434455; this version posted March 8,2021 . The copyright holder for this preprint (which was not certified by peer review) is the author/funder, who has granted bioRxiv a license to display the preprint in perpetuity. It is made available under aCC-BY-NC-ND 4.0 International license.
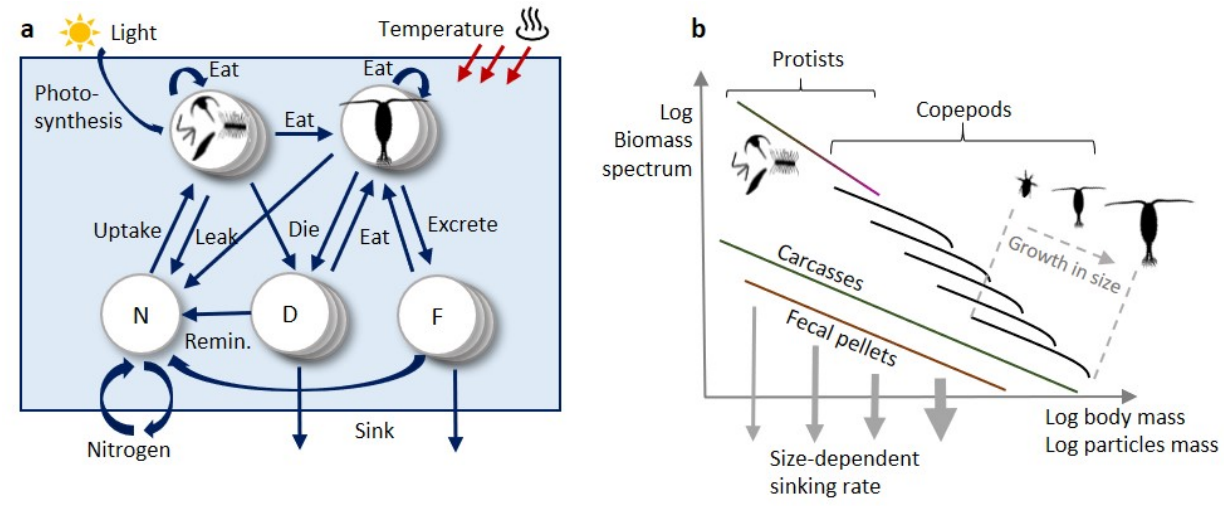

Figure 1. (a) Diagram of the interactions between model compartments: nitrogen $(N)$, protists $(P)$, copepods $(C)$, fecal pellets $(F)$, and carcasses $(D)$. (b) Illustration of the outcome of the model in terms of unicellular, multicellular. Except for the nitrogen pool, all compartments are represented by a size-spectrum (lines). For the copepods, each black line is a copepod population, and the community spectrum is formed by adding all the size-spectra together (protists+copepods). Fecal pellets and carcasses have size-dependent sinking rates.

figuration and resulting community trait-composition emerge from the environmental forcing (nitrogen, light, temperature), and from competition and predation.

Organisms in the model interact through competition and predation (Fig. 1). Copepods feed on protists, on other copepods and on carcasses and fecal pellets. Protists feed on other protists, but also have the ability to perform photosynthesis and take up dissolved nitrogen. Food that is not assimilated by copepods is excreted as fecal pellets. The dead cells/bodies of organisms that die through viral lysis or other background mortality enters the carcasses compartment. Sinking rate of fecal pellets and carcasses is sizedependent. Overall, the model is mechanistic, i.e., we use empirically demonstrated mechanisms at the individual level to scale to the population, community and ecosystem levels.

In the following we explain the model. We first go through the model compartments and interactions to show the processes affecting the dynamics of each compartment. The remaining equations representing individual level processes of copepods and protists are in the supporting information (section B). Next, we describe the modelled physical environment, the numerical simulations, and the data used to test the model. The supporting information contains additional figures (section A), and all parameter values, the remaining equations, and a list of the changes and extensions made to the model relative to the original version in Serra-Pompei et al. (2020) (section B).

\subsection{Model compartments}

The model is a system of coupled ordinary differential equations (ODEs) (table 1). The main compartments are (Fig. 1): copepods $(C)$, protists $(P)$, fecal pellets $(F)$, carcasses $(D)$, and nitrogen $(N)$. Each compartment is represented by a number of size-classes (each corresponding to one ODE) that result in a size-distribution (except for the nitrogen compartment). Thus, each ODE simulates the change in time of the biomass concentration $\left(\mathrm{mgC} \mathrm{m}^{-3} \mathrm{~d}^{-1}\right.$ or $\left.\mathrm{mgN} \mathrm{m} \mathrm{m}^{-3} \mathrm{~d}^{-1}\right)$ within a size class. Each size-class is characterised by the mass $m$, which is the geometric mean body- or particle mass in $\mu \mathrm{gC}$. 
bioRxiv preprint doi: https://doi.org/10.1101/2021.03.08.434455; this version posted March 8,2021 . The copyright holder for this preprint (which was not certified by peer review) is the author/funder, who has granted bioRxiv a license to display the preprint in perpetuity. It is made available under aCC-BY-NC-ND 4.0 International license.

Table 1. Equations of all the model compartments. Terms appearing in this table are specified in table 2. Indexes are: $s$ for a copepod size-class within a population $i$, and $k, l, j$ are each size class of protists, fecal pellets and carcasses respectively. Capital letters of the same indices represent the total number of size-classes in each compartment. For the fecal pellets and carcasses, the sums of all the rates originating from copepods and protists are summed only for the size ranges corresponding to each size group of the detritus.

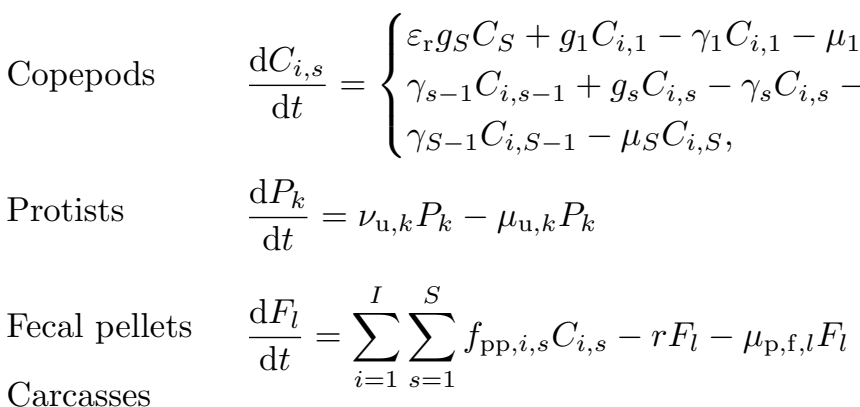

$$
\begin{aligned}
& \text { (dead cells } \\
& \text { and cope- } \\
& \text { pods) } \\
& \text { Nitrogen } \\
& \frac{\mathrm{d} D_{j}}{\mathrm{~d} t}=\sum_{k=1}^{K} \mu_{\mathrm{u} k} P_{k}+\sum_{i=1}^{I} \sum_{s=1}^{S}\left(\delta \mu_{\mathrm{htli,s}} C_{i, s}\right)-r D_{j}-\mu_{\mathrm{p}, \mathrm{D}, j} D_{j} \\
& \frac{\mathrm{d} N}{\mathrm{~d} t}=\frac{1}{Q_{\mathrm{C}: \mathrm{N}}}\left[r\left(\sum_{l=1}^{L} F_{l}+\sum_{j=1}^{J} D_{j}\right)+\sum_{k=1}^{K}\left(\eta_{\text {leaks. } k}-\eta_{\mathrm{N} . k}\right) P_{k}\right. \\
& \left.+\eta_{\mathrm{DON}, s}+\sum_{i=1}^{I} \sum_{s=1}^{S}(1-\delta) \mu_{\mathrm{htl}, i, s} C_{i, s}\right]
\end{aligned}
$$

The size spectrum of each compartment can be derived (see section 2.2). In the following section we explain the ODEs of each compartment.

\subsubsection{Copepods}

Each copepod population is resolved by $s$ stages. Individuals are born in stage $s=$ 1 and grow through the stages until adulthood $(s=S)$. Thus, each population is represented by a system of $S$ ODEs (Eq. 1). Growth $(g)$ is the outcome of food consumption, assimilation, respiration and starvation (see appendix B and tables B.3 and B.7 therein). For juveniles, the net energy gains are invested into growth of body-mass. As organisms grow, they switch to larger size-classes. This is represented by the maturation term $\gamma$. Mortality $\mu$ originates from predation by other copepods and a density-dependent closure term that represents mortality by higher trophic levels. Finally, all the energy gained by adults $g_{S}$ is invested into reproduction. Overall, the life-cycle of copepod populations is closed, maintaining the mass-balance through reproduction and growth.

\subsubsection{Protists}

The biomass of protists increases with protists growth $\nu_{\mathrm{u}, k}$ and decreases with total mortality $\mu_{\mathrm{u}, k}$ (Eq. 2, and equations in SI. B.4 and table B.5). Protists can simultaneously do photosynthesis, take up dissolved nutrients, and prey on other protists. The trophic strategy (autotrophy, mixotrophy or heterotrophy) emerges from the size-scaling of uptake rates and the available light and resources (nutrients and food). Thus, protists may compete for all resources with other protists size-classes but also for prey with 
bioRxiv preprint doi: https://doi.org/10.1101/2021.03.08.434455; this version posted March 8,2021 . The copyright holder for this preprint (which was not certified by peer review) is the author/funder, who has granted bioRxiv a license to display the preprint in perpetuity. It is made available under aCC-BY-NC-ND 4.0 International license.

Table 2. Rates appearing in table 1 . All rates are in units of day ${ }^{-1}$ except $\eta_{\text {DON }}$ which is in $\mu \mathrm{gC} \mathrm{L}^{-1} \mathrm{~d}^{-1}$. Equations of these rates are in the supporting information section $\mathrm{B}$ following the equation numbers of the last column in this table.

\begin{tabular}{llr}
\hline Symbol & Description & Equation \# in the SI \\
\hline$g_{s}$ & Biomass accumulation within each copepod stage & Eq. B.3.4 \\
$\gamma_{s}$ & Maturation rate copepods & Eq. B.3.5 \\
$\mu_{s}$ & Total mortality rate copepods & Eq. B.3.8 \\
$\nu_{\mathrm{u}}$ & Growth rate protists & Eq. B.5.3 \\
$\mu_{\mathrm{u}}$ & Total mortality rate protists & Eq. B.5.5 \\
$f_{\mathrm{pp}}$ & Fecal pellet production by copepods & Eq. B.3.6 \\
$\mu_{\mathrm{p}, \mathrm{f}}$ & Consumption of fecal pellets by copepods & Eq. B.7.1 \\
$r$ & Remineralization rate of fecal pellets or carcasses & Tab. B.6 \\
$\mu_{\mathrm{htl}}$ & Mortality by higher trophic levels on copepods & Eq. B.3.11 \\
$\mu_{\mathrm{p}, \mathrm{D}}$ & Consumption of carcasses by copepods & Eq. B.7.2 \\
$\eta_{\text {leaks }}$ & Nitrogen leaks by protists & Eq. B.5.4 \\
$\eta_{\mathrm{N}}$ & Nitrogen uptake by protists & Eq. B.5.1 \\
$\eta_{\mathrm{DON}}$ & Nitrogen excretion by copepods & Eq. B.3.7 \\
\hline
\end{tabular}

copepods. Growth is the result of the most limiting element (carbon or nitrogen). Surplus of nitrogen is leaked back to the environment ( $\left.\eta_{\text {leaks }}\right)$. Protists have two sources of mortality: predation and viral lysis. Predation originates from other protists or copepods.

\subsubsection{Fecal pellets and carcasses}

Fecal pellets $(F$, Eq. 3$)$ are produced by copepods $\left(f_{\mathrm{pp}}\right)$. Biomass of carcass $(D$, Eq. 4) increases with viral lysis of protists $\left(\mu_{\mathrm{u}, \mathrm{b} 0}\right)$ and a fraction $\delta$ of the mortality by higher trophic levels of copepods $\left(\mu_{\mathrm{htl}}\right)$. Both fecal pellets and carcasses are remineralized $(r)$ or eaten by other copepods $\left(\mu_{\mathrm{p}, \mathrm{f}, l}\right)$ without any preference function for size, as it has been shown that copepods can feed on detrital particles larger than themselves (Kiørboe, 2000; Koski et al., 2020).

\subsubsection{Nitrogen}

Dissolved nitrogen ( $N$, Eq. 5$)$ is taken up by protists $\eta_{N}$. Its concentration increases through bacterial remineralization $r$, leakage from protists $\eta_{\text {leaks }}$ and excretion from copepods $\eta_{\text {DON }}$. Higher trophic levels, not explicitly considered in the model, respire carbon and excrete nitrogen back to the environment. Thus, we assume that a fraction $1-\delta$ of the losses to higher trophic levels $\mu_{\mathrm{htl}}$ is remineralized.

\subsection{Biomass spectrum}

From the biomass in each size-class, we can obtain a size distribution of the biomass. We refer to this distribution as the biomass spectrum. The biomass spectrum is obtained by dividing the biomass in each size range by the size-range itself. For example, the size spectrum of protists is $P_{k \text {,spec }}=P_{k} / \Delta_{P}$, and thus the units of the biomass spectrum become $\mathrm{mgC} \mathrm{m}^{-3} \mathrm{\mu gC}^{-1}$. This normalization of all size classes allows comparison between compartments, even if the size-classes are of different sizes (see Sprules \& Barth, 2016 and chapter 2 of Andersen, 2019 for more explanations regarding size-spectra conversions). 


\subsection{Physical model}

The NUM framework is embedded in a physical model of the global ocean. Physics are simulated by the transport matrix method (Khatiwala et al., 2005; Khatiwala, 2007). We use a coarse resolution $\left(2.8^{\circ} \times 2.8^{\circ}, 15\right.$ vertical levels $)$, monthly-averaged transport matrix from the MIT gcm (http://kelvin.earth.ox.ac.uk/spk/Research/TMM/TransportMatrixConfigs, as used in Dutkiewicz, Follows, \& Parekh, 2005). The temperature forcing is also monthly averaged and was provided in the transport matrix itself. Irradiance at the ocean surface was taken from the http://sites.science.oregonstate.edu/ocean.productivity/index.phpOcean Productivity site. The data was afterwards interpolated to fit the grid of the transport matrix. The irradiance experienced by primary producers in each layer is as follows: surface irradiance is $I_{0}$ and the incoming irradiance in the upper boundary $\left(z_{i, u p}\right)$ of each depth-layer $z_{i}$ is:

$$
I_{z, u p}=I_{0} e^{-k_{t o t} z_{i, u p}},
$$

where $k_{t o t}$ is the attenuation coefficient, which depends on the attenuation coefficient of seawater $k_{w}\left(\mathrm{~m}^{-1}\right)$ and on the attenuation by planktonic particles $k_{p}\left(\mathrm{~m}^{2} \mathrm{mgC}^{-1}\right)$ :

$$
k_{t o t}=k_{w}+k_{p} \int_{0}^{z_{i}} P \mathrm{~d} z .
$$

The realised light experienced by plankton in each depth layer is the mean of the light level in the depth bin:

$$
I_{z}=\frac{I_{z, u p}}{k_{t o t} \Delta_{z, i}}\left(1-e^{-k_{t o t} \Delta_{z, i}}\right),
$$

where $\Delta_{z, i}$ is the depth range in each grid of the transport matrix.

\subsection{Carbon export}

The sinking rate of fecal pellets and carcasses is implemented as a simple first order upwind scheme in the transport matrix. Hence, the rate of change of a state variable $X$ due to sinking $v_{\text {sink }}$ in each depth bin $(z)$ is:

$$
X_{z} t=\frac{v_{\text {sink }}}{\Delta_{z}}\left(X_{z-1}-X_{z}\right) ;
$$

where $X$ denotes carcasses or fecal pellets particles concentration in a bin $(z), v_{\text {sink }}$ the sinking rate (in $\mathrm{m} \mathrm{d}^{-1}$ ) associated to the particle and $\Delta_{z}$ the depth-range of the bin (in $\mathrm{m}$ ). Therefore this sinking term affects the ODEs from $F$ and $D$ (Eq. 3 and 4 respectively).

The sinking rate attributed to each particle depends on the particle size $m$ within each size-class (Fig. A.10). Fecal pellets sinking rates are relatively well constrained, and we use the data from Small et al. (1979). Carcasses sinking rates are highly uncertain since the particles might change size as they sink by coagulation, fragmentation or changes in density. We do not model these processes and assume a sinking rate that is only weakly dependent on particles size, consistent with observations (Alldredge \& Gotschalk, 1988).

\subsection{Carbon export efficiency (pe-ratio)}

The pe-ratio is defined as the fraction of depth-integrated NPP exported as sinking particles. Here, we consider the annual and seasonal pe-ratio. The annual pe-ratio is the ratio between NPP and export flux integrated over a year. The seasonal pe-ratio is on a shorter time scale, and is the daily particle flux divided by the two weeks averaged NPP previous to the carbon flux (as in Henson et al., 2019). All carbon export ef- 
bioRxiv preprint doi: https://doi.org/10.1101/2021.03.08.434455; this version posted March 8, 2021. The copyright holder for this preprint (which was not certified by peer review) is the author/funder, who has granted bioRxiv a license to display the preprint in perpetuity. It is made available under aCC-BY-NC-ND 4.0 International license.

ficiencies are measured at $170 \mathrm{~m}$ depth, which corresponds to the third depth-layer of the transport matrix.

\subsection{Numerics}

The model configuration is flexible. Any reasonable number of state variables can be implemented. Here, we use $K=14$ protists size-classes, and $I=9$ copepod populations ( 6 populations of active feeding copepods and 3 populations of passive feeding copepods). Each population has $S=5$ stages. There are $L=8$ size classes of fecal pellets and $J=8$ size-classes of detritus. There is one pool of dissolved nitrogen. The model was implemented in MATLAB and run for 20 years. The code can be found in github reprository https://github.com/cam-sp/NUMmodel_global.git.

\subsection{Model testing}

Outputs of the model were compared with field data extracted from the literature. Copepod biomass was compared with data collected in an Atlantic meridional transect by López and Anadón (2008). López and Anadón (2008) used a small mesh, and therefore collected most of the copepod size range. Protists biomass was compared with nanoand microplankton data from San Martin et al. (2006), from three Atlantic Meridional Transects (Fig. A.15). To compare net primary production (NPP) we use field data collected in different campaigns (Fig. 6). For particle export, we used the data compiled in Le Moigne et al. (2013) and extended in Henson et al. (2019). In this data-set, the particle flux at a $100 \mathrm{~m}$ depth is estimated by the $234 \mathrm{Th}$ technique.

\section{Results}

We start by describing the general trends of biomass and energy fluxes in the food web while comparing them with data. Next, we investigate the drivers of food web configurations and associated particle export efficiency (pe-ratio). All the fluxes discussed are yearly-integrated except in the the last section (3.5) where we consider seasonality.
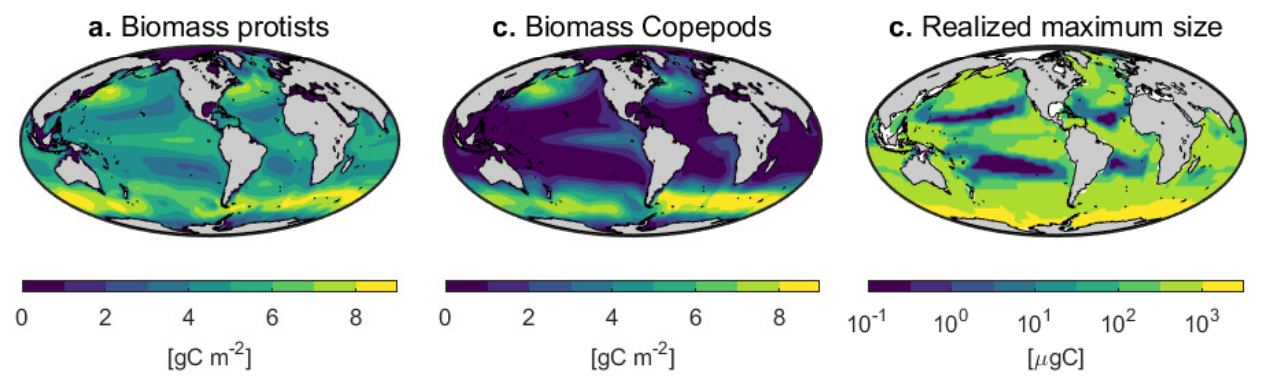

Figure 2. Yearly averaged biomass of (a) protists and (b) copepods. (c) Realized maximum size, calculated as the size where the $95 \%$ of the cumulative biomass lies (as shown in Fig. A.11). 


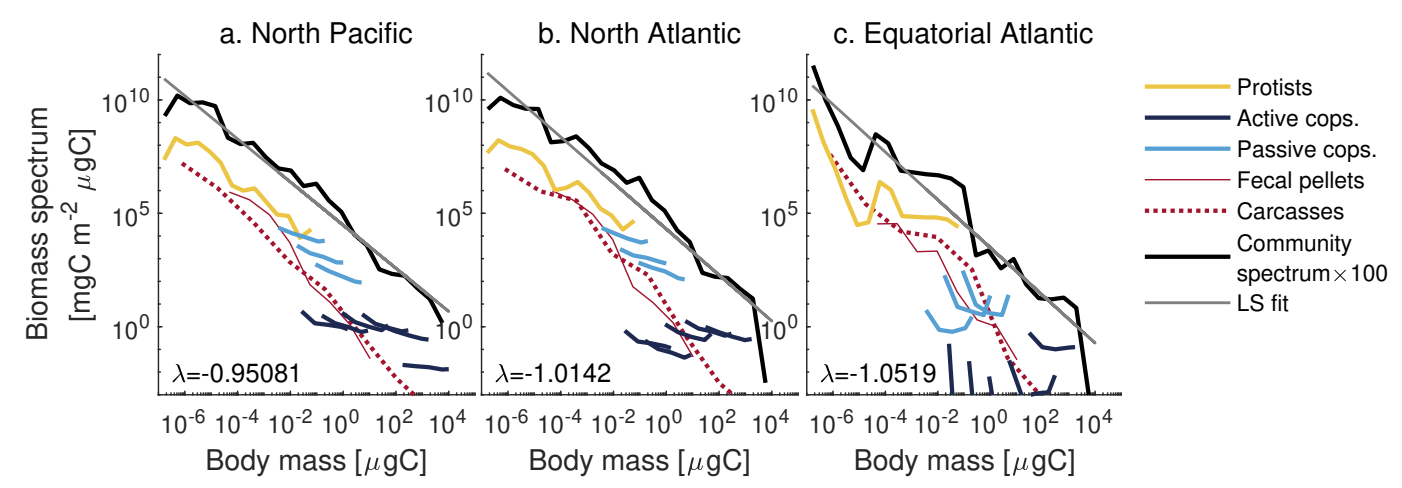

Figure 3. Biomass spectra of the community and detrital particles for three ocean locations: protists (yellow), active copepods (dark blue), passive copepods (light blue), fecal pellets (red, continuous line), and carcasses (red, dotted). Biomass spectra of the community (black, we multiplied it by 100 for better visualisation), and least square fit (grey line). To calculate the community spectrum, the community was divided into 24 logarithmic evenly distributed mass groups, and therefore the resolution is coarser than the spectra of each group. $\lambda$ is the exponent of the fit. Community spectrum does not include detritus.

\subsection{Biomass}

Both protists and copepod biomass follow the same latitudinal trends (Fig. 2): high in temperate, sub-polar, and lowest in oligotrophic gyres. Compared with field-data, copepod biomass (Fig. 4) is underestimated at low latitudes and overestimated in higher latitudes of the southern hemisphere. Still, biomass trends were similar and within the same order of magnitude in most cases.

In temperate regions, copepods of several sizes coexist, whereas at low latitudes rather large copepods dominate (in terms of biomass, Fig. 3 end 4). The latter does not match the data, which shows a relatively constant size distribution across latitudes (Fig. 4b). This highlights a lack of coexistence in the model in regions of low productivity. In these regions, the present size-classes seem to be driven by the imposed predator-prey size-ratio matching the dominant protists.

We used biomass data of nano- and microplankon to compare with protists biomass of the model (Fig. A.14). In this case the model falls within observed biomass ranges, however we do not capture some peaks of biomass that occur at single stations. For instance, we do not capture the high biomass close to coastal regions in the AMT 13 transect, probably due to the coarse resolution of the transport matrix. The rest of predicted biomass patterns of copepods and protists fit fairly well the data and are of similar orders of magnitude.

\subsection{Size spectrum}

The model produces a size spectrum of the community (Fig. 3 and A.13). We fitted a power-law function to the community biomass spectrum to obtain the coefficient $(\kappa)$ and the exponent $(\lambda)$. The coefficient of the community spectrum (which basically represents community biomass) changes with productivity (Fig. A.13a), with higher coefficients in more productive regions. The exponent is always close to -1 , with small variations (Fig. A.13b). The small changes in the exponent seem to be driven by the presence/absence of the smallest protists size-classes and the largest copepods (Fig. 3). The 
bioRxiv preprint doi: https://doi.org/10.1101/2021.03.08.434455; this version posted March 8,2021 . The copyright holder for this preprint (which was not certified by peer review) is the author/funder, who has granted bioRxiv a license to display the preprint in perpetuity. It is made available under aCC-BY-NC-ND 4.0 International license.
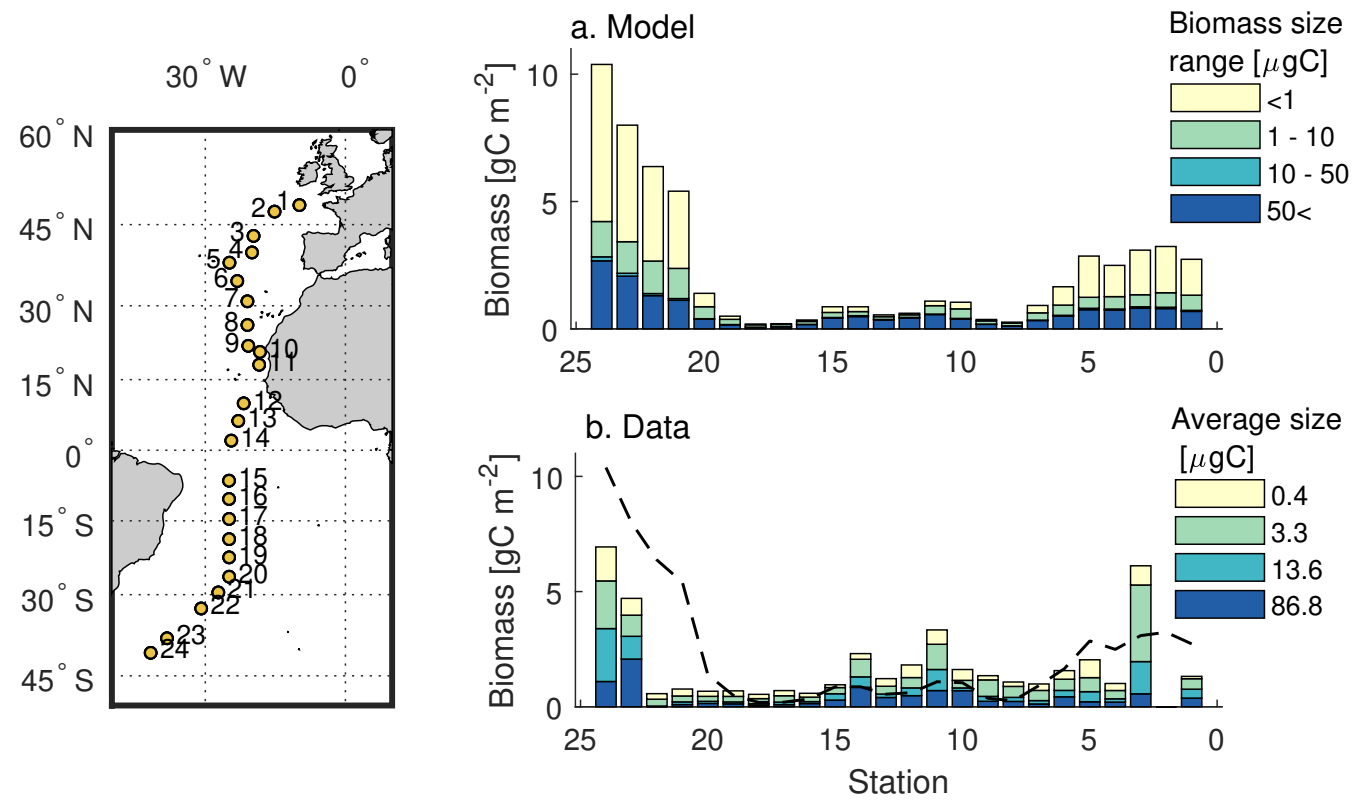

Figure 4. Copepod biomass along the Atlantic Meridional Transect for different body-size ranges. (a) Model estimates. (b) Data from López and Anadón (2008), obtained by multiplying the abundance by the average body-mass within each size range from field data. The smallest size-class combines adult copepods and nauplii. The dashed line is the total copepod biomass from the model (in panel a). Left panel shows the stations where the data was collected in López and Anadón (2008).

absence of larger copepods in low productive regions suggests that there are limits to how many trophic levels a given energy input can support, i.e. low NPP cannot sustain many higher trophic levels. We thus looked at the realized maximum size that can be reached in a food web (Fig. 2c and A.11). This term is defined as the body-mass that contain $95 \%$ of the cumulative biomass of the whole community (Fig. A.11). In the examples provided, low latitudes have low biomass and most biomass is concentrated in the smallest size-classes (Fig. A.11). In temperate and high latitudes, the total biomass density is high and biomass is spread over a broader range.

The number of trophic levels in the food web is determined by a combination of resource limitation and metabolic expenses. On one hand, low resources result in low energy inputs and tend to favour small cells. On the other hand, temperature increases metabolic rates. However, most resource-acquisition rates have a lower temperature dependency than metabolic costs (table B.8 and Serra-Pompei et al., 2019). Therefore, given the same amount of resources, growth efficiency is lower at higher temperatures. Thus, by increasing metabolic rates and decreasing nutrients supply (through stronger stratification), temperature decreases the biomass of copepods, as most energy is lost through respiration. The resulting energy available for higher trophic level relative to total NPP is thus lower at high temperatures (Fig. A.12). The opposite happens in cold regions. These differences result in most energy staying in the microbial food web at low latitudes and being transferred more efficiently to higher trophic levels at high latitudes. Ultimately, temperature decreases the high pe-ratio associated to copepods. 
bioRxiv preprint doi: https://doi.org/10.1101/2021.03.08.434455; this version posted March 8, 2021. The copyright holder for this preprint (which was not certified by peer review) is the author/funder, who has granted bioRxiv a license to display the preprint in perpetuity. It is made available under aCC-BY-NC-ND 4.0 International license.
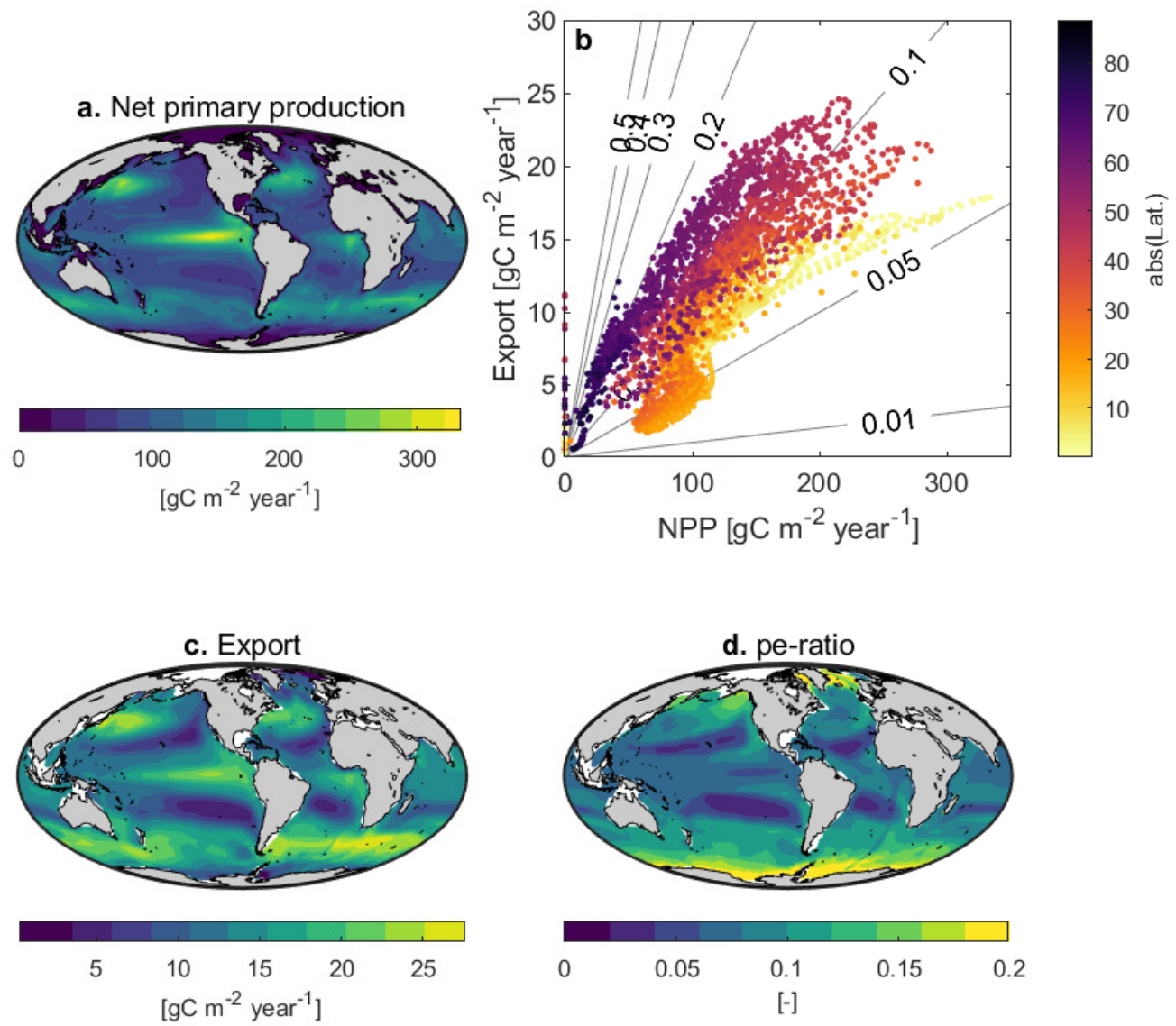

Figure 5. (a) Yearly depth integrated net primary production, (b) NPP vs. export at $170 \mathrm{~m}$; colors are absolute latitude, contour lines are the pe-ratio. (c) Carbon export at $170 \mathrm{~m}$. (d) pe-ratio.

\subsection{Primary production, predation and export flux}

Annual NPP is high in temperate and equatorial regions and lowest in the oligotrophic gyres (Fig. 5). The annual global NPP is $49 \mathrm{PgC} \mathrm{year}^{-1}$ above $85 \mathrm{~m}$ (and $65 \mathrm{PgC}$ year $^{-1}$ above $170 \mathrm{~m}$ ). This global value falls within the range of global NPP estimated by remote sensing (between 36 and $78 \mathrm{PgC}$ year ${ }^{-1}$, Carr et al., 2006). When comparing NPP model output by regions (Fig. 6b), the model fits fairly well at low latitudes but underestimates in temperate regions. In the Southern Ocean and in the Arabian Sea, the model underestimates NPP by a factor of 3 .

There is a clear partition of the NPP flow through the food web (Fig. 7). Protists always consume about half of the NPP, with higher values in low latitudes. Copepod predation is almost insignificant in oligotrophic regions. At higher latitudes, copepods consume up to $80 \%$ of the NPP produced. This does not necessarily mean that copepods only consume primary producers, but instead that copepods play a considerable role in channeling energy through the food web. Predation by copepods on other copepods is much lower with the highest values being around $10 \%$ of the NPP. This is because energy is being lost through the first trophic steps between protists and from protists to 

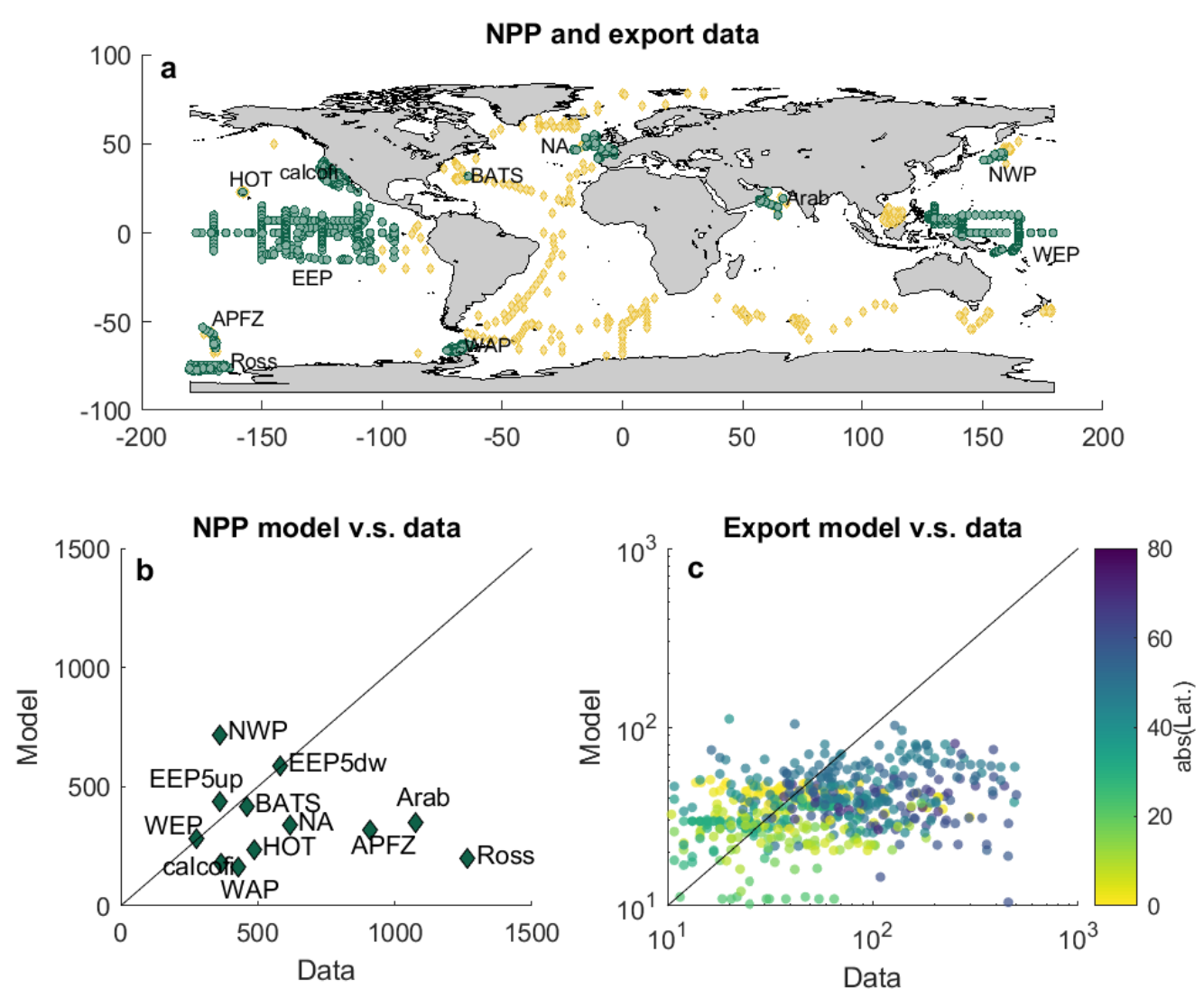

Figure 6. (a) NPP (green) and export (yellow) estimates $\left(\mathrm{mgC} \mathrm{m}^{-2} \mathrm{day}^{-1}\right)$ compiled from the literature. (b) data vs. model of NPP averaged by regions: eastern equatorial Pacific above $5^{\circ} \mathrm{N}$ (EEP5up) and below $5^{\circ} \mathrm{N}$ (EEP5dw), Hawaii Ocean Time Series (HOT), California Cooperative Oceanic Fisheries Investigations (calcofi), Bermuda Atlantic Time Series (BATS), North Atlantic (NA), Arabian Sea (Arab), western equatorial Pacific (WEP), north-west Pacific (NWP), Antarctic Circumpolar frontal Zone experiments (APFZ), Ross Sea (Ross). Data was compiled from: Friedrichs et al. (2009), Saba et al. (2011), Shiomoto (2000), Imai et al. (2002), and www.calcofi.org. (c) Export data vs. model. Export flux measurements were made using the 234Th technique at a $100 \mathrm{~m}$ and were obtained from the data synthesis of Le Moigne et al. (2013) and updated in Henson et al. (2019). Model export was calculated at at $170 \mathrm{~m}$ depth due to the coarse resolution of the transport matrix.

copepods. Finally, in most regions, more than half of the total detritus produced is consumed by copepods.

Global carbon flux is $5.26 \mathrm{PgC}_{\text {year }}{ }^{-1}$ at $85 \mathrm{~m}$ (and $4.03 \mathrm{PgC}_{\text {year }}{ }^{-1}$ at $170 \mathrm{~m}$ ). Carbon flux is high at high latitudes and low in oligotrophic regions (Fig. 5c). The spread of our carbon flux is smaller than the observations (Fig. 6), where our model outputs range between 10 and $100 \mathrm{mgC} \mathrm{m}^{-2}$ day $^{-1}$, whereas observations reach up to a $1000 \mathrm{mgC} \mathrm{m}^{-2}$ day $^{-1}$. The highest observed values are in subpolar and polar regions, where the model does not perform very well. This might be due to the lack of diatoms and hibernation of copepods in the model. In addition, due to the coarse resolution of the transport matrix we compare export at $170 \mathrm{~m}$ instead of at $100 \mathrm{~m}$ as in the data, which leads to some 
bioRxiv preprint doi: https://doi.org/10.1101/2021.03.08.434455; this version posted March 8, 2021. The copyright holder for this preprint (which was not certified by peer review) is the author/funder, who has granted bioRxiv a license to display the preprint in perpetuity. It is made available under aCC-BY-NC-ND 4.0 International license.

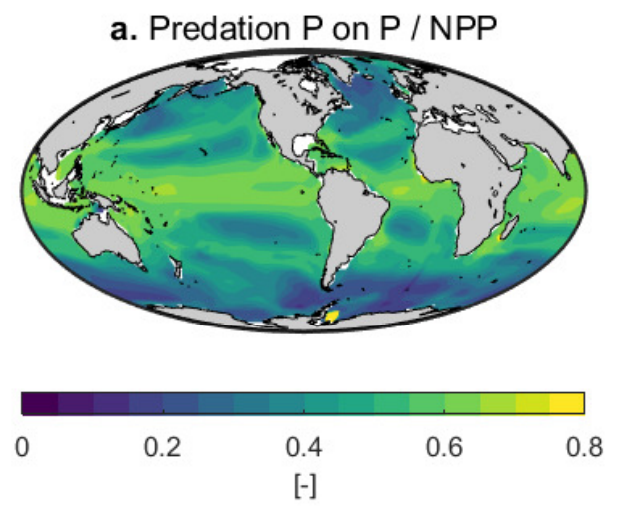

c. Predation C on C / NPP

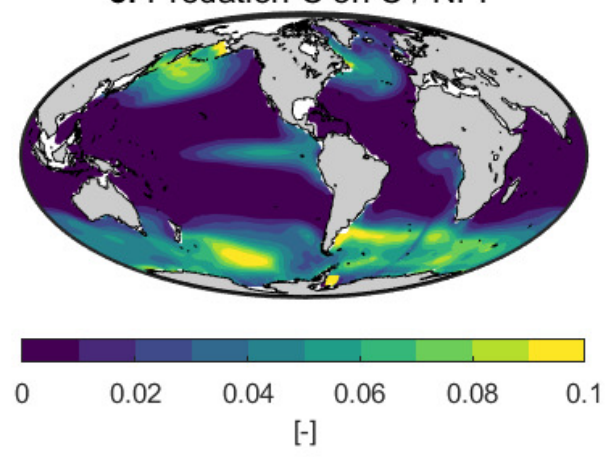

b. Predation C on P / NPP

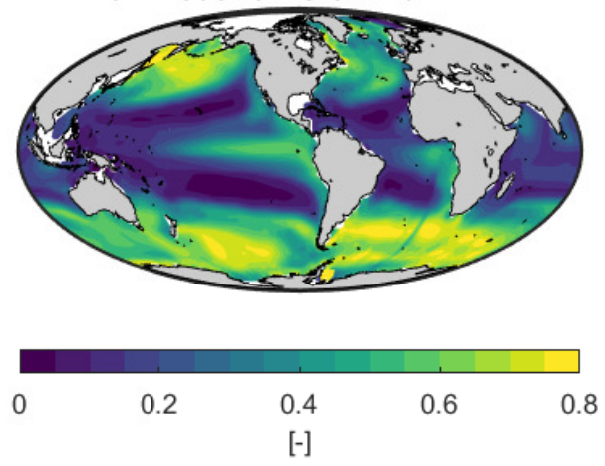

d. Detritus consumption / detritus production

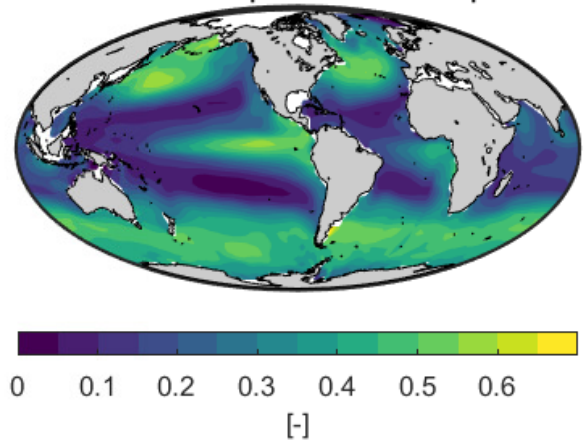

Figure 7. Predation loss rates relative to NPP or detritus consumption. (a) predation by protists on protists relative to NPP. (b) Predation by copepods on protists relative to NPP. (c) Predation by copepods on copepods relative to NPP. (d) Predation by copepods on detritus + fecal pellets relative to production of detritus + fecal pellets.

systematic underestimate of the model. All in all, the model is less variable than the data and misses the highest values.

Vertical profiles of carbon export show that export originating from carcasses is attenuated faster than the fecal pellet flux (Fig. A.16). This is due to the slower sinking rate of carcasses. The flux associated with fecal pellets is highly variable (Fig. A.16), due to the copepods biomass and size differences across regions. Due to the faster sinking rate, copepod fecal pellets are the main form of detritus reaching the deep ocean.

\subsection{Carbon export efficiency}

There is a positive trend between carbon export and NPP (Fig. 5b), with a spread across latitudes, resulting in different export efficiencies (pe-ratios). The yearly pe-ratio ranges between $\approx 0$ to 0.2 in the model (Fig. $5 \mathrm{~d}$ ). As a first approach to identify the relation between pe-ratio and other variables we performed a correlation analysis between export efficiency and a large number of model outputs such as other absolute and relative fluxes or biomass (Fig. 8 and A.17). 
bioRxiv preprint doi: https://doi.org/10.1101/2021.03.08.434455; this version posted March 8, 2021. The copyright holder for this preprint (which was not certified by peer review) is the author/funder, who has granted bioRxiv a license to display the preprint in perpetuity. It is made available under aCC-BY-NC-ND 4.0 International license.

The strongest positive correlations with pe-ratio is the fraction of NPP consumed by copepods (Fig. A.17c). This shows the importance of copepods - and their fecal pellets - in determining the pe-ratio. However, pe-ratio did not have a clear relation with copepod biomass (Fig. A.17a); transfer efficiency towards copepods is a more important factor than biomass in determining pe-ratio. The strongest negative trend is with temperature. NPP is also negatively correlated with pe-ratio. Due to the low seasonality and high irradiance, yearly integrated NPP is high at low latitudes, probably giving the inverse relation between NPP and pe-ratio. Obviously, many of these processes are correlated themselves, i.e. regions with high temperatures are strongly stratified and thus have low inputs of nitrogen and higher remineralization rates.

The strong negative relation between temperature and export efficiency is associated with the high biomass of copepods. Copepods, which produce fast-sinking fecal pellets, dominate in cold regions (Fig. 2 and 4). Conversely, protists, associated with slow sinking rates of particles, dominate at warmer low latitudes (Fig. 2 and 7). In addition, higher remineralization rates in warm regions also contribute to a decreased export efficiency. Finally, despite consuming more than half of the detritus produced, detritus consumption by copepods was not strongly related to pe-ratio (Fig. 8d). However, we did not consider particle fragmentation (Mayor et al., 2020). Thus, the only means by which copepods affect detritus is by trophic transfer losses. All in all, temperature is the strongest predictor of pe-ratio (Fig. 8 and A.17), but it works indirectly by affecting the energy reaching copepods. If the energy reaching copepods is high, the flux by fecal pellets is efficient.
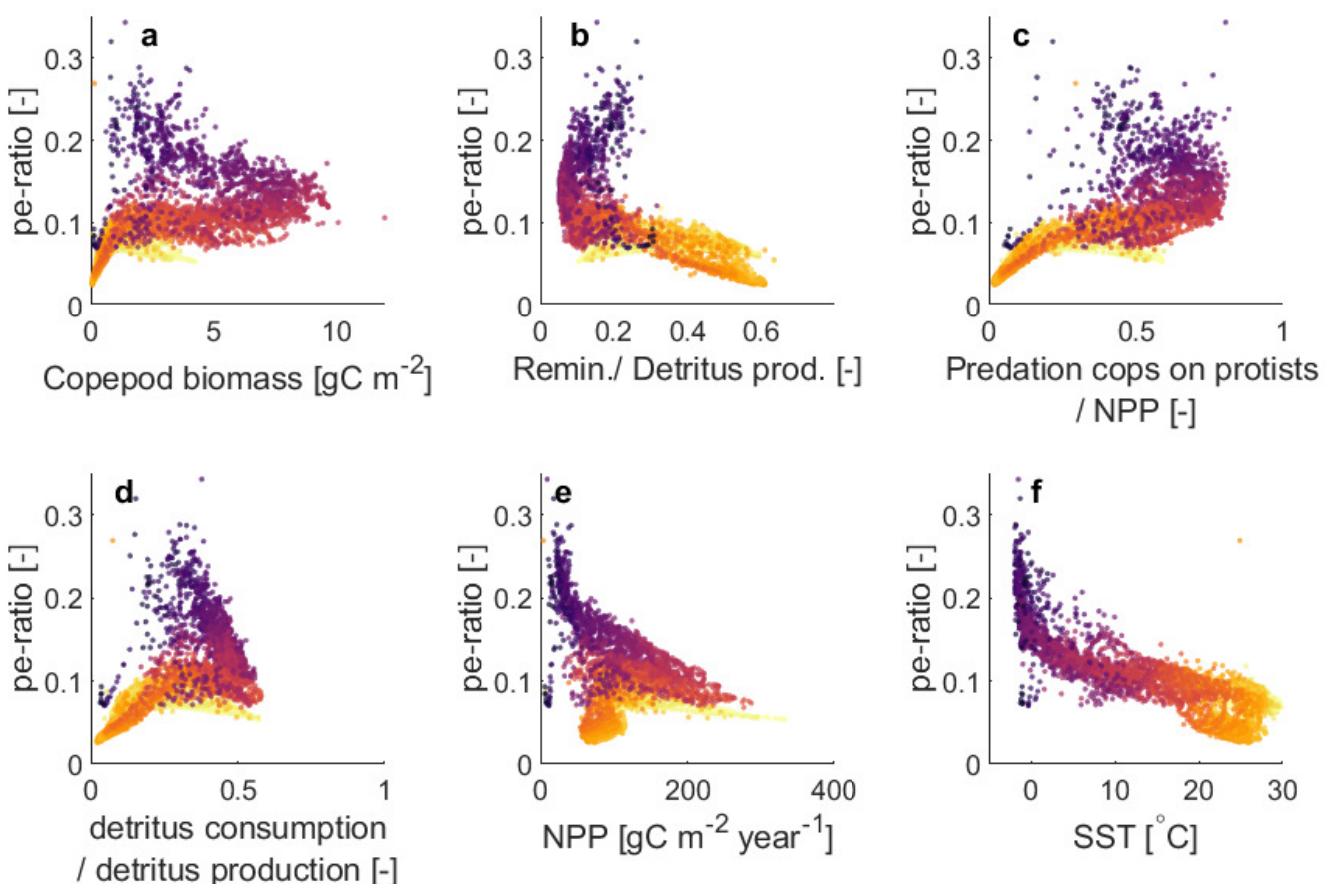

Figure 8. Correlation between fluxes and biomasses to pe-ratio sorted into latitude ranges: low latitudes ( $30 \mathrm{~S}$ to $30 \mathrm{~N}$ ), temperate ( $45 \mathrm{~S}$ to $30 \mathrm{~S}$ and $30 \mathrm{~N}$ to $70 \mathrm{~N}$ ) and polar (above $45 \mathrm{~S}$ and $70 \mathrm{~N})$. Biomasses are yearly averaged and fluxes are yearly integrated. Each point represents a 2.8 $\times 2.8$ degree grid cell. 
bioRxiv preprint doi: https://doi.org/10.1101/2021.03.08.434455; this version posted March 8,2021 . The copyright holder for this preprint

\subsection{Seasonality and top-down control}

Until now we considered yearly integrated rates. However, the dynamics of export efficiency vary over the season. We were interested in examining two mechanisms, namely how top-down control and seasonal dynamics affected pe-ratio. To examine this, we looked at three regions with different seasonal dynamics and pe-ratios: North Pacific, North Atlantic and Equatorial Atlantic (Fig. 9). The north Pacific (high pe-ratio) and equatorial Atlantic (low pe-ratio) have low biomass variability throughout the year and have similar NPP but different pe-ratios, while the North Atlantic experiences a strong variability in pe-ratio.

In the North Pacific, copepods follow the dynamics of protists (Fig. 9a), suggesting top-down control. However, in this system pe-ratio is high (Fig. 9g). Thus, top-down control does not necessarily result in low pe-ratios. On the other hand, there is a large spring bloom of protists in the North Atlantic (Fig. 9b), where copepods are unable to follow and control the growth rate of protists. In this case, the pe-ratio is lowest during the growing phase of the bloom (no top-down control), and increases as copepods appear and take control of the protist production. The pe-ratio is highest in winter, where NPP and export are at their lowest (Fig. 9h). However, in this case, pe-ratio dynamics seem to be driven by the fast changes in NPP rather than export by itself (Fig. 9e and h).

In the north Atlantic, the export flux generally lags behind NPP and smooths out the short-time fluctuations in NPP (Fig. 9e). For example, note the very high pe-ratio when NPP quickly decreases due to copepod grazing after the bloom. The peak in peratio after the bloom matches the decreased NPP and not the peak in export. Here we calculated the pe-ratio using the two-week-averaged NPP prior to the carbon flux. Still, it seems like this time-span was not large enough to compensate for the fast dynamics of NPP relative to export. Thus, in systems with strong seasonal dynamics, the different relative rates of changes of NPP and export play an important role in determining the pe-ratio at short time-scales.

\section{Discussion}

We have analyzed the drivers of carbon export efficiency by sinking particles (peratio) with a mechanistic trait-based model which resolves the size structure of both the planktonic community and the sinking detritus. The model accommodates emergent food web configurations, and makes it possible to explore the details of the complex contributions to the export flux that are hard to dissect from observations. We find that carbon export efficiency increases when NPP is channeled through the copepod compartment due to the production of fast-sinking fecal pellets. Temperature indirectly influences this process by affecting metabolic rates and nitrogen availability, which affect growth efficiency and trophic transfer. Finally, top-down control does not necessarily affect peratio, the relationship varies depending on the predator imposing the top-down control and on the dynamics of NPP relative to the carbon flux.

\subsection{Mechanisms driving food web structure, size spectrum and export efficiency}

Temperature is the best predictor of pe-ratio in the model. However, temperature acts mainly indirectly on the pe-ratio, as its effect on resource supply and metabolic expenses in plankton is stronger than its effect on the remineralization rate of detritus. Temperature decreases the nitrogen availability (due to higher stratification) and increases metabolic rates, that in turn reduce organismal growth efficiency. This combination of temperature and nutrient limitation results in a low input of energy in the system and most of this energy is lost as respiration. Low growth efficiencies due to nutrient limi- 
bioRxiv preprint doi: https://doi.org/10.1101/2021.03.08.434455; this version posted March 8, 2021. The copyright holder for this preprint (which was not certified by peer review) is the author/funder, who has granted bioRxiv a license to display the preprint in perpetuity. It is made available under aCC-BY-NC-ND 4.0 International license.

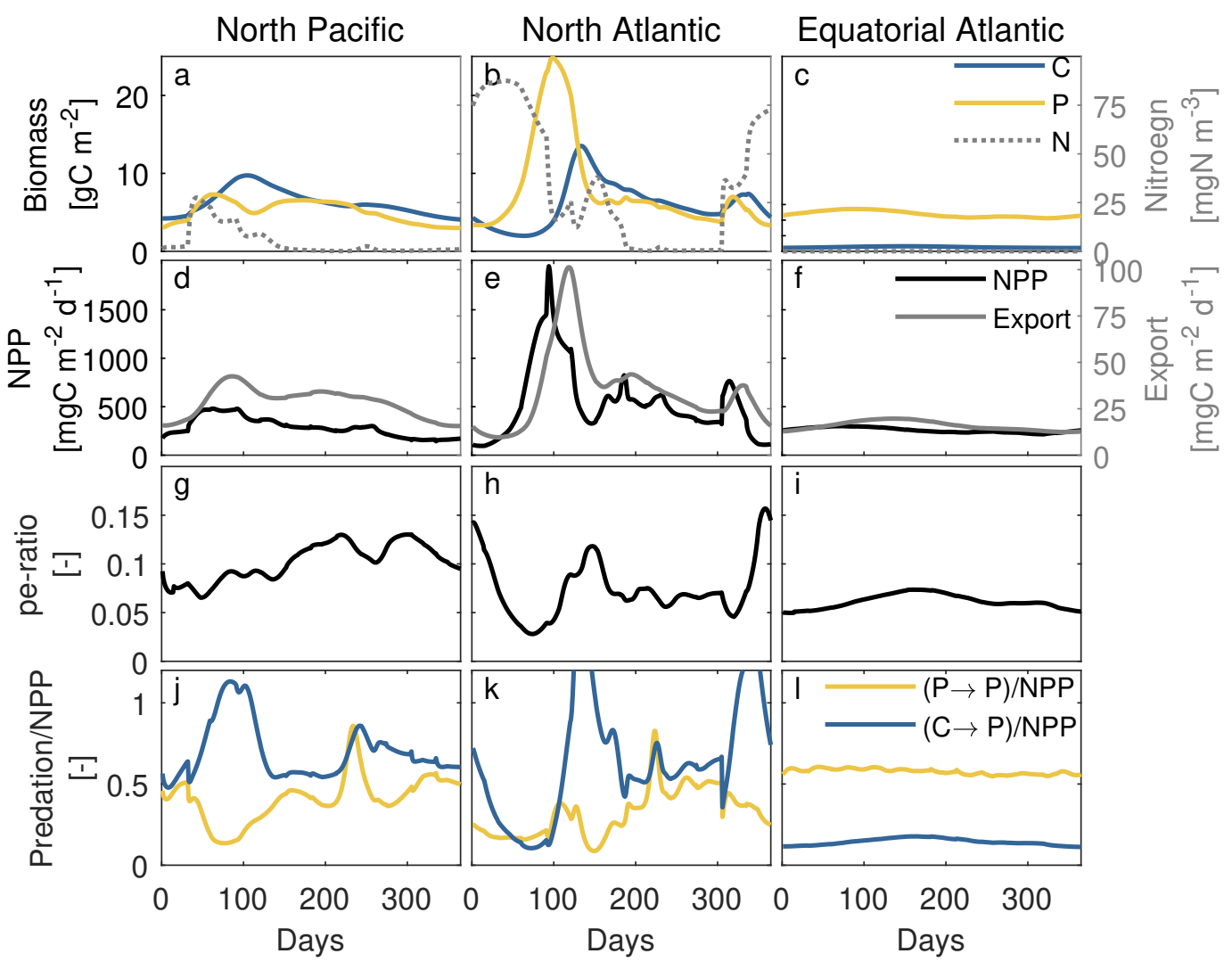

Figure 9. Seasonal dynamics in the North Pacific, North Atlantic and Equatorial Atlantic. $(\mathbf{a}, \mathbf{b}, \mathbf{c})$ left y-axis: biomass of protists (yellow) and copepods (blue). Right y-axis (grey) is the nitrogen concentration in the surface layer (dotted). (d,e,f) NPP (left y-axis, black) and carbon flux at $170 \mathrm{~m}$ (right y-axis, grey). (g,h,i) pe-ratio. (j, k, l) Predation by protists on protists relative to NPP (yellow) and predation by copepods on protists relative to NPP (blue).

tation at high temperature have been shown for bacteria from field data (López \& Anadón, 2008), and in experiments for phytoplankton (Marañón et al., 2018). In copepods, a low growth efficiency at higher temperatures has been found by combining field and laboratory experiments (Ikeda et al., 2001), although it is unclear whether that was due to resource limitation or not. These studies support the results from the model, and indicate that growth efficiency is an important factor in supporting higher trophic levels and associated pe-ratio.

The exponent of the biomass spectrum is always close to -1 , with slight variations, in agreement with size-spectrum theory and data obtained in plankton communities (Sprules \& Munawar, 1986; San Martin et al., 2006; Andersen, 2019). In warm regions, biomass accumulates in the microbial community due to the lower growth efficiencies (as discussed above) and the resulting lower trophic transfer efficiencies to higher trophic levels. We find that temperature and growth efficiency affects the exponent of the biomass spectrum. The inverse relation between temperature and growth efficiency is similar to the trophic amplification observed in other modelling studies in relation to climate change. In this phenomenon, higher trophic levels are more affected than lower trophic levels by rising temperatures and associated nutrient limitation (Kirby \& Beaugrand, 2009; Stock et al., 2014; Kwiatkowski et al., 2019). 


\subsection{Top-down control and NPP dynamics}

Top-down control per se is weakly related to carbon export efficiency. Of higher importance is the size range over which top-down control acts, and the effect this has on the particle spectra and concomitant sinking rates. For example, in the North Pacific, large copepods exert a strong predation pressure but pe-ratio is high. This result is counter to the theoretical predictions of Parsons (1988). In their study, they argued that regions with strong top-down control had low carbon export due to the energy staying in the food web of the upper ocean. Henson et al. (2019) also related their findings to this mechanism. By compiling field-data, Henson et al. (2019) found high pe-ratios when nitrogen levels were high, which they used as a proxy for pre-bloom conditions, and thus as a proxy for an "uncoupled trophic system". We found high pe-ratios in the winter months previous to the spring bloom, but that was from the rapid changes in NPP relative to plankton biomass and associated carbon flux.

Henson et al. (2019) found an inverse relation between pe-ratio and NPP and Laws and Maiti (2019) argued that this was due to the effects of time lags between NPP and measured export. Accounting for this time-lag explained several of the observations related to NPP and pe-ratio. Note, however, that when integrating over the year, we do find a negative trend between NPP and pe-ratio. There is thus a difference between timescales that need to be considered when discussing export efficiencies.

Despite the significant grazing of detritus by copepods, the flux was not strongly attenuated in our simulations. This is in contrast to other studies (Wexels Riser et al., 2007, 2010; Cavan et al., 2017; Mayor et al., 2020), that argued that copepods can strongly attenuate the carbon flux by fragmenting detrital particles. This disagreement may be because we do not consider particle fragmentation. Therefore, losses by simple trophic transfer are not enough to attenuate the flux. Fragmentation of particles by copepods should be incorporated in future models.

\subsection{Sinking rates of particles}

Ultimately, our sinking-rate assumptions define the pe-ratio. In the model, sinking rates of dead cells and carcasses are lower than the sinking rates of most fecal pellets. This defines the main result of the model: high pe-ratios associated with the presence of copepods and relatively low pe-ratios associated with protists. The sinking rates of fecal pellets were obtained from data (Small et al., 1979) and the assumed sinking rate of dead cells also fell within those reported in the literature (e.g. Alldredge \& Gotschalk, 1988; Bach et al., 2019). However, the sinking rate of particles changes with particles density and other factors (Bach et al., 2019). In addition, particle density and size can change due to physical factors (e.g. aggregation of particles), which are not considered in the model. Therefore, to accurately predict particles carbon flux, dynamics of sinking particles should be taken into account.

Finally, we are missing some plankton functional groups that can strongly contribute to carbon export. For instance, diatoms and diatom aggregates sink fast but are not present in the model (Roca-Martí et al., 2017). A diatom bloom would have a fast sinking rate if not grazed. However, diatom blooms are a transient phenomena, and may not strongly increase the annual pe-ratio, except perhaps in polar regions. Gelatinous zooplankton can also largely contribute to carbon export (Luo et al., 2020). Both gelatinous zooplankton and diatoms need different parametrizations relative to their carbon mass, size, and sinking (Kiørboe, 2013; Hansen \& Visser, 2019; Cadier et al., 2020), and therefore have not been included in the model. 


\subsection{Model performance and limitations}

We do not represent diel and seasonal vertical migrations of zooplankton. Vertical migrations play an important role in the survival and life cycle of copepods, and in carbon export (Jónasdóttir et al., 2015; Hansen \& Visser, 2016; Steinberg \& Landry, 2017). Implementing vertical migrations may be done through an optimisation (e.g. Pinti et al., 2019; Brun et al., 2019). Implementing behaviour together with population dynamics is, however, challenging, specially if considered at the global scale. However, implementing the active export pathway is important, since other modelling studies have suggested that the active carbon flux, and not passive export, might have been responsible of increasing the efficiency of the biological carbon pump (Fakhraee et al., 2020).

The lack of ontogenetic migration among zooplankton, and the lack of diatoms in the model result in a bad performance of the model at high latitudes. All else, the model seems to fit fairly well the data. Yet, the coarse resolution of the transport matrix prevents detailed comparisons. In particular, a finer resolution in the vertical dimension would be helpful to better capture phytoplankton and NPP dynamics. Another limitation of the model is the lack of nutrients other than nitrogen. This might affect plankton dynamics in some regions. An example is the effect of iron limitation in the Southern Ocean and other regions of the world, which can limit phytoplankton growth.

Finally, size-spectrum models have been vastly used in the past to model fish communities (Andersen et al., 2016; Guiet et al., 2016; Andersen, 2019). Recently, zooplankton size-spectrum models have emerged. Heneghan et al. (2020) developed a size-spectrum model of different zooplankton functional groups and fish dynamics at the global scale. We, on the other hand, represent the other extreme of the food web: primary producers and the microbial loop. These works show the potential of zooplankton size-spectrum models to link primary producers to fish production and develop new end-to-end models.

\section{Conclusion}

We have used a size- and trait- based model of the plankton community to understand the mechanisms by which zooplankton drive carbon export efficiency. We find that the way energy flows in the food web, together with community composition, strongly influences carbon export efficiency. In this regard, the larger the fraction of NPP channeled through the copepod compartment, the higher the pe-ratio. Temperature regulates the flow of energy in the food web by directly affecting metabolic rates and indirectly through resource limitation. Here, high temperatures decrease growth efficiency, trophic transfer and the resulting carbon export efficiency, as most energy is lost through respiration in the microbial food web. Top-down control by copepod grazing affect carbon export efficiency whereas top-down control from protists does not. Finally, we found a negative trends between NPP and export efficiency at the annual level but no clear relation at shorter time-scales. At the seasonal level, the fast rate of NPP relative to plankton biomass and concomitant export was the main factor defining pe-ratio at short time scales.

The model presented here builds upon previous work of size-based, emergent food web models (e.g. Follows et al., 2007; Bruggeman \& Kooijman, 2007; Ward et al., 2012; Chakraborty et al., 2020). However, most of these models center on the microbial community. Zooplankton play an important role in driving carbon export (Turner, 2015; Steinberg \& Landry, 2017). To better understand this process, improving zooplankton representation in global biogeochemical models is needed. We have presented a model that resolves the life cycle and size distribution of the planktonic community. This also resolves the associated size distribution and sinking rates of fecal pellets, which are major contributors to the carbon flux (Le Moigne, 2019). Thus, efforts to improve the rep- 
resentation of zooplankton in global models seem a promising avenue to improve our understanding of the carbon cycle and sequestration in the deep ocean.

\section{Acknowledgments}

This work was supported by the Gordon and Betty Moore Foundation through award 5479, and by the Centre for Ocean Life, a VKR Centre for Excellence funded by the Villum Foundation. B.A.W. was funded by a Royal Society University Research Fellowship.

\section{References}

Aksnes, D. L., \& Wassmann, P. (1993). Modeling the significance of zooplankton grazing for export production. Limnology and Oceanography, 38(5), 978-985. doi: https://doi.org/10.4319/lo.1993.38.5.0978

Alldredge, A. L., \& Gotschalk, C. (1988). In situ settling behavior of marine snow 1. Limnology and Oceanography, 33(3), 339-351. doi: https://doi.org/10.4319/lo .1988 .33 .3 .0339

Andersen, K. H. (2019). Fish ecology, evolution, and exploitation: a new theoretical synthesis. Princeton University Press. (ISBN: 0691192952, 9780691192956)

Andersen, K. H., Jacobsen, N. S., \& Farnsworth, K. D. (2016). The theoretical foundations for size spectrum models of fish communities. Canadian Journal of Fisheries and Aquatic Sciences, 73(4), 575-588. doi: https://doi.org/10.1139/ cjfas-2015-0230

Bach, L. T., Stange, P., Taucher, J., Achterberg, E. P., Algueró-Muñiz, M., Horn, H., ... Riebesell, U. (2019). The influence of plankton community structure on sinking velocity and remineralization rate of marine aggregates. Global Biogeochemical Cycles, 33(8), 971-994. doi: https://doi.org/10.1029/2019GB006256

Bruggeman, J., \& Kooijman, S. A. (2007). A biodiversity-inspired approach to aquatic ecosystem modeling. Limnology and Oceanography, 52(4), 1533-1544. doi: https://doi.org/10.4319/lo.2007.52.4.1533

Brun, P., Stamieszkin, K., Visser, A. W., Licandro, P., Payne, M. R., \& Kiørboe, T. (2019). Climate change has altered zooplankton-fuelled carbon export in the north atlantic. Nature ecology \& evolution, 3(3), 416-423. doi: https://doi.org/10.1038/s41559-018-0780-3

Cadier, M., Hansen, A. N., Andersen, K. H., \& Visser, A. W. (2020). Competition between vacuolated and mixotrophic unicellular plankton. Journal of Plankton Research, 42(4), 425-439. doi: https://doi.org/10.1093/plankt/fbaa025

Carr, M.-E., Friedrichs, M. A., Schmeltz, M., Aita, M. N., Antoine, D., Arrigo, K. R., ... others (2006). A comparison of global estimates of marine primary production from ocean color. Deep Sea Research Part II: Topical Studies in Oceanography, 53(5-7), 741-770. doi: https://doi.org/10.1016/ j.dsr2.2006.01.028

Cavan, E. L., Henson, S. A., Belcher, A., \& Sanders, R. (2017). Role of zooplankton in determining the efficiency of the biological carbon pump. Biogeosciences, 14, 177-186. doi: https://doi.org/10.5194/bg-14-177-2017

Chakraborty, S., Cadier, M., Visser, A. W., Bruggeman, J., \& Andersen, K. H. (2020). Latitudinal variation in plankton traits and ecosystem function. Global Biogeochemical Cycles, 34(8). doi: https://doi.org/10.1029/2020GB006564

Chakraborty, S., Nielsen, L. T., \& Andersen, K. H. (2017). Trophic strategies of unicellular plankton. The American Naturalist, 189(4), E77-E90. doi: http:// orcid.org/0000-0003-4177-3205

de Roos, A. M., Schellekens, T., Van Kooten, T., Van De Wolfshaar, K., Claessen, D., \& Persson, L. (2008). Simplifying a physiologically structured population model to a stage-structured biomass model. Theoretical population biology, 73 (1), 47-62. doi: https://doi.org/10.1016/j.tpb.2007.09.004 
DeVries, T., \& Weber, T. (2017). The export and fate of organic matter in the ocean: New constraints from combining satellite and oceanographic tracer observations. Global Biogeochemical Cycles, 31 (3), 535-555.

doi: https://doi.org/10.1002/2016GB005551

Ducklow, H. W., Steinberg, D. K., \& Buesseler, K. O. (2001). Upper ocean carbon export and the biological pump. OCEANOGRAPHY-WASHINGTON DCOCEANOGRAPHY SOCIETY-, 14(4), 50-58. doi: https://doi.org/10.5670/ oceanog.2001.06

Dunne, J. P., Armstrong, R. A., Gnanadesikan, A., \& Sarmiento, J. L. (2005). Empirical and mechanistic models for the particle export ratio. Global Biogeochemical Cycles, 19(4). doi: https://doi.org/10.1029/2004GB002390

Dutkiewicz, S., Follows, M. J., \& Parekh, P. (2005). Interactions of the iron and phosphorus cycles: A three-dimensional model study. Global Biogeochemical Cycles, 19(1). doi: https://doi.org/10.1029/2004GB002342

Fakhraee, M., Planavsky, N. J., \& Reinhard, C. T. (2020). The role of environmental factors in the long-term evolution of the marine biological pump. Nature Geoscience, 13(12), 812-816. doi: https://doi.org/10.1038/s41561-020-00660-6

Follows, M. J., Dutkiewicz, S., Grant, S., \& Chisholm, S. W. (2007). Emergent biogeography of microbial communities in a model ocean. science, 315(5820), 1843-1846. doi: 10.1126/science.1138544

Friedrichs, M. A., Carr, M.-E., Barber, R. T., Scardi, M., Antoine, D., Armstrong, R. A., ... others (2009). Assessing the uncertainties of model estimates of primary productivity in the tropical pacific ocean. Journal of Marine Systems, 76 (1-2), 113-133. doi: https://doi.org/10.1016/j.jmarsys.2008.05.010

Guiet, J., Poggiale, J.-C., \& Maury, O. (2016). Modelling the community sizespectrum: recent developments and new directions. Ecological Modelling, 337, 4-14. doi: https://doi.org/10.1016/j.ecolmodel.2016.05.015

Hansen, A. N., \& Visser, A. W. (2016). Carbon export by vertically migrating zooplankton: an optimal behavior model. Limnology and Oceanography, 61(2), 701-710. doi: https://doi.org/10.1002/lno.10249

Hansen, A. N., \& Visser, A. W. (2019). The seasonal succession of optimal diatom traits. Limnology and Oceanography, 64(4), 1442-1457. doi: https://doi.org/ 10.1002/lno.11126

Heneghan, R. F., Everett, J. D., Sykes, P., Batten, S. D., Edwards, M., Takahashi, K., .. Richardson, A. J. (2020). A functional size-spectrum model of the global marine ecosystem that resolves zooplankton composition. Ecological Modelling, 435, 109265. doi: https://doi.org/10.1016/j.ecolmodel.2020.109265

Henson, S., Le Moigne, F., \& Giering, S. (2019). Drivers of carbon export efficiency in the global ocean. Global Biogeochemical Cycles, 33(7), 891-903. doi: https://doi.org/10.1029/2018GB006158

Henson, S., Sanders, R., Madsen, E., Morris, P. J., Le Moigne, F., \& Quartly, G. D. (2011). A reduced estimate of the strength of the ocean's biological carbon pump. Geophysical Research Letters, 38(4). doi: https://doi.org/10.1029/ 2011GL046735

Ikeda, T., Kanno, Y., Ozaki, K., \& Shinada, A. (2001). Metabolic rates of epipelagic marine copepods as a function of body mass and temperature. Marine Biology, 139(3), 587-596. doi: https://doi.org/10.1007/s002270100608

Imai, K., Nojiri, Y., Tsurushima, N., \& Saino, T. $\quad$ (2002). Time series of seasonal variation of primary productivity at station knot (44 n, 155 e) in the sub-arctic western north pacific. Deep Sea Research Part II: Topical Studies in Oceanography, 49(24-25), 5395-5408. doi: https://doi.org/10.1016/ S0967-0645(02)00198-4

Jónasdóttir, S. H., Visser, A. W., Richardson, K., \& Heath, M. R. (2015). Seasonal copepod lipid pump promotes carbon sequestration in the deep north atlantic. Proceedings of the National Academy of Sciences, 112(39), 12122-12126. doi: 
bioRxiv preprint doi: https://doi.org/10.1101/2021.03.08.434455; this version posted March 8,2021 . The copyright holder for this preprint (which was not certified by peer review) is the author/funder, who has granted bioRxiv a license to display the preprint in perpetuity. It is made available under aCC-BY-NC-ND 4.0 International license.

https://doi.org/10.1073/pnas.1512110112

Khatiwala, S. (2007). A computational framework for simulation of biogeochemical tracers in the ocean. Global Biogeochemical Cycles, 21(3). doi: https://doi .org/10.1029/2007GB002923

Khatiwala, S., Visbeck, M., \& Cane, M. A. (2005). Accelerated simulation of passive tracers in ocean circulation models. Ocean Modelling, 9(1), 51-69. doi: https://doi.org/10.1016/j.ocemod.2004.04.002

Kiørboe, T. (2000). Colonization of marine snow aggregates by invertebrate zooplankton: abundance, scaling, and possible role. Limnology and Oceanography, 45(2), 479-484. doi: https://doi.org/10.4319/lo.2000.45.2.0479

Kiørboe, T. (2013). Zooplankton body composition. Limnology and Oceanography, 58(5), 1843-1850. doi: https://doi.org/10.4319/lo.2013.58.5.1843

Kirby, R. R., \& Beaugrand, G. (2009). Trophic amplification of climate warming. Proceedings of the Royal Society B: Biological Sciences, 276(1676), 40954103. doi: https://doi.org/10.1098/rspb.2009.1320

Koski, M., Valencia, B., Newstead, R., \& Thiele, C. (2020). The missing piece of the upper mesopelagic carbon budget? biomass, vertical distribution and feeding of aggregate-associated copepods at the pap site. Progress in Oceanography, 181, 102243. doi: https://doi.org/10.1016/j.pocean.2019.102243

Kwiatkowski, L., Aumont, O., \& Bopp, L. (2019). Consistent trophic amplification of marine biomass declines under climate change. Global change biology, 25(1), 218-229. doi: https://doi.org/10.1111/gcb.14468

Laws, E. A., D'Sa, E., \& Naik, P. (2011). Simple equations to estimate ratios of new or export production to total production from satellite-derived estimates of sea surface temperature and primary production. Limnology and Oceanography: Methods, 9(12), 593-601. doi: https://doi.org/10.4319/lom.2011.9.593

Laws, E. A., Falkowski, P. G., Smith Jr, W. O., Ducklow, H., \& McCarthy, J. J. (2000). Temperature effects on export production in the open ocean. Global Biogeochemical Cycles, 14(4), 1231-1246. doi: https://doi.org/10.1029/ 1999GB001229

Laws, E. A., \& Maiti, K. (2019). The relationship between primary production and export production in the ocean: Effects of time lags and temporal variability. Deep Sea Research Part I: Oceanographic Research Papers, 148, 100-107. doi: https://doi.org/10.1016/j.dsr.2019.05.006

Le Moigne, F. (2019). Pathways of organic carbon downward transport by the oceanic biological carbon pump. Frontiers in Marine Science, 6, $634 . \quad$ doi: https://doi.org/10.3389/fmars.2019.00634

Le Moigne, F., Henson, S., Sanders, R., \& Madsen, E. ～(2013). Global database of surface ocean particulate organic carbon export fluxes diagnosed from the 234th technique. $\quad$ Earth System Science Data, 5(2), 295-304. doi: https://doi.org/10.5194/essd-5-295-2013

Longhurst, A. R., \& Harrison, W. G. (1989). The biological pump: profiles of plankton production and consumption in the upper ocean. Progress in Oceanography, 22(1), 47-123.

López, E., \& Anadón, R. (2008). Copepod communities along an atlantic meridional transect: Abundance, size structure, and grazing rates. Deep Sea Research Part I: Oceanographic Research Papers, 55(10), 1375-1391. doi: https://doi.org/10.1016/0079-6611(89)90010-4

Luo, J. Y., Condon, R. H., Stock, C. A., Duarte, C. M., Lucas, C. H., Pitt, K. A., \& Cowen, R. K. (2020). Gelatinous zooplankton-mediated carbon flows in the global oceans: A data-driven modeling study. Global Biogeochemical Cycles, 34 (9), e2020GB006704. doi: https://doi.org/10.1029/2020GB006704

Maiti, K., Charette, M. A., Buesseler, K. O., \& Kahru, M. (2013). An inverse relationship between production and export efficiency in the southern ocean. Geophysical Research Letters, 40(8), 1557-1561. doi: https://doi.org/10.1002/grl 
bioRxiv preprint doi: https://doi.org/10.1101/2021.03.08.434455; this version posted March 8,2021 . The copyright holder for this preprint (which was not certified by peer review) is the author/funder, who has granted bioRxiv a license to display the preprint in perpetuity. It is made available under aCC-BY-NC-ND 4.0 International license.

.50219

Marañón, E., Lorenzo, M. P., Cermeño, P., \& Mouriño-Carballido, B.

(2018)

Nutrient limitation suppresses the temperature dependence of phytoplankton metabolic rates. The ISME journal, 12(7), 1836-1845.

doi: https://doi.org/10.1038/s41396-018-0105-1

Mayor, D. J., Gentleman, W. C., \& Anderson, T. R. $\quad$ (2020). Ocean carbon sequestration: Particle fragmentation by copepods as a significant unrecognised factor? explicitly representing the role of copepods in biogeochemical models may fundamentally improve understanding of future ocean carbon storage. BioEssays, 42(12), 2000149. doi: https://doi.org/10.1002/bies.202000149

Parsons, T. R. (1988). Trophodynamic phasing in theoretical, experimental aud natural pelagic ecosystems. Journal of the Oceanographical Society of Japan, 44(2), 94-101. doi: https://doi.org/10.1007/BF02303124

Pinti, J., Kiørboe, T., Thygesen, U. H., \& Visser, A. W. (2019). Trophic interactions drive the emergence of diel vertical migration patterns: a game-theoretic model of copepod communities. Proceedings of the Royal Society B, 286(1911), 20191645. doi: https://doi.org/10.1098/rspb.2019.1645

Roca-Martí, M., Puigcorbé, V., Iversen, M. H., van der Loeff, M. R., Klaas, C., Cheah, W., ... Masqué, P. (2017). High particulate organic carbon export during the decline of a vast diatom bloom in the atlantic sector of the southern ocean. Deep Sea Research Part II: Topical Studies in Oceanography, 138, 102-115. doi: https://doi.org/10.1016/j.dsr2.2015.12.007

Saba, V. S., Friedrichs, M. A., Antoine, D., Armstrong, R., Asanuma, I., Behrenfeld, M., ... others (2011). An evaluation of ocean color model estimates of marine primary productivity in coastal and pelagic regions across the globe. Biogeosciences, 489-503. doi: https://doi.org/10.5194/bg-8-489-2011

San Martin, E., Harris, R. P., \& Irigoien, X. (2006). Latitudinal variation in plankton size spectra in the atlantic ocean. Deep Sea Research Part II: Topical Studies in Oceanography, 53(14-16), 1560-1572. doi: https://doi.org/10.1016/j.dsr2 .2006 .05 .006

Serra-Pompei, C., Hagstrom, G. I., Visser, A. W., \& Andersen, K. H. (2019). Resource limitation determines temperature response of unicellular plankton communities. Limnology and Oceanography, 64(4), 1627-1640. doi: https://doi.org/10.1002/lno.11140

Serra-Pompei, C., Soudijn, F., Visser, A. W., Kiørboe, T., \& Andersen, K. H. (2020). A general size-and trait-based model of plankton communities. Progress in Oceanography, 102473. doi: https://doi.org/10.1016/ j.pocean.2020.102473

Shiomoto, A. (2000). Chlorophyll-a and primary production during spring in the oceanic region of the oyashio water, the north-western pacific. Journal of the Marine Biological Association of the United Kingdom, 80(2), 343-354. doi: https://doi.org/10.1017/S0025315499001927

Small, L., Fowler, S., \& Ünlü, M. (1979). Sinking rates of natural copepod fecal pellets. Marine Biology, 51(3), 233-241. doi: https://doi.org/10.1007/ BF00386803

Sprules, W. G., \& Barth, L. E. (2016). Surfing the biomass size spectrum: some remarks on history, theory, and application. eries and Aquatic Sciences, 73(4), 477-495. Canadian Journal of Fishcjfas-2015-0115

doi: https://doi.org/10.1139/

Sprules, W. G., \& Munawar, M. (1986). Plankton size spectra in relation to ecosystem productivity, size, and perturbation. Canadian Journal of Fisheries and Aquatic Sciences, 43(9), 1789-1794. doi: https://doi.org/10.1139/f86-222

Stamieszkin, K., Pershing, A. J., Record, N. R., Pilskaln, C. H., Dam, H. G., \& Feinberg, L. R. (2015). Size as the master trait in modeled copepod fecal pellet carbon flux. Limnology and Oceanography, 60(6), 2090-2107. doi: 
https://doi.org/10.1002/lno.10156

Steinberg, D. K., \& Landry, M. R. (2017). Zooplankton and the ocean carbon cycle. Annual Review of Marine Science, 9, 413-444. doi: https://doi.org/10 .1146/annurev-marine-010814-015924

Stock, C., Dunne, J., \& John, J. (2014). Drivers of trophic amplification of ocean productivity trends in a changing climate. Biogeosciences Discussions, 11(7). doi: https://doi.org/10.5194/bg-11-7125-2014

Turner, J. T. (2015). Zooplankton fecal pellets, marine snow, phytodetritus and the ocean's biological pump. Progress in Oceanography, 130, 205-248. doi: https://doi.org/10.1016/j.pocean.2014.08.005

Ward, B. A., Dutkiewicz, S., Jahn, O., \& Follows, M. J. (2012). A size-structured food-web model for the global ocean. Limnology and Oceanography, 57(6), 1877-1891. doi: https://doi.org/10.4319/lo.2012.57.6.1877

Wexels Riser, C., Reigstad, M., \& Wassmann, P. (2010). Zooplankton-mediated carbon export: A seasonal study in a northern norwegian fjord. Marine Biology Research, 6(5), 461-471. doi: https://doi.org/10.1080/17451000903437067

Wexels Riser, C., Reigstad, M., Wassmann, P., Arashkevich, E., \& Falk-Petersen, S. (2007). Export or retention? copepod abundance, faecal pellet production and vertical flux in the marginal ice zone through snap shots from the northern barents sea. Polar Biology, 30(6), 719-730. doi: https://doi.org/10.1007/ s00300-006-0229-z 